\title{
Total incombustible (mineral) content of Cherax quadricarinatus differs between feral populations in Central- Eastern Australia
}

\author{
Leyton J. Tierney ${ }^{1}{ }^{\text {, }}$ Clyde H. Wild ${ }^{1}{ }^{\text {, James M. Furse }}{ }^{\text {Corresp. } 2,3}$ \\ 1 Environmental Futures Research Institute, Griffith University, Gold Coast, Queensland, Australia \\ 2 Griffith Centre for Coastal Management, Griffith University, Gold Coast, Queensland, Australia \\ 3 Miyazaki International College, Miyazaki, Japan \\ Corresponding Author: James M. Furse \\ Email address: j.furse@griffith.edu.au
}

Cherax quadricarinatus has been widely translocated within Australia, and a number of self-sustaining feral populations have established, and persisted, in central-eastern Australia for over 20 years: however the biology and ecology of feral populations remain poorly understood. Using the loss-by-ignition method, this study investigated differences in the total content of incombustible material (as a proxy for total mineral content), between feral C. quadricarinatus populations in southeast Queensland and northeastern New South Wales. One hundred and two C. quadricarinatus were ignited, and percent total incombustible material was not proportional to the body size, or gender of the crayfish. Incombustible content was however significantly different between some locations of capture (i.e. waterbodies). The site where incombustible content in crayfish was atypical, Lake Ainsworth, is a naturally acidic coastal lake, and we suggest that acidity and low concentration of calcium in that waterbody are likely responsible for the difference in mineral content detected in that population. Mechanism(s) driving the difference detected in the Lake Ainsworth population are unknown, but we suggest the acidic environment could directly impact maintenance of internal calcium reserves in the crayfish (intermoult), during recalcification of the cuticle (postmoult), or both. Limited calcium availability in the Lake may also be a direct, or indirect contributing factor. The ability of $C$. quadricarinatus to occupy acidic habitats while managing biomineralisation challenges could possibly enable additional range-expansion of the species, and potential impacts on both endangered ecological communities, and other biota occupying the acidic coastal habitats of Eastern Australia. 
1 Incombustible (mineral) content of Cherax quadricarinatus differs between feral

2 populations in Central-Eastern Australia.

3

4 Leyton J. Tierney ${ }^{1}$, Clyde H.Wild ${ }^{1}$, James M. Furse ${ }^{2,3}$

5

6 1Environmental Futures Research Institute, Gold Coast campus, Griffith University, Gold Coast,

7 Queensland 4222, Australia.

8

$9{ }^{2}$ Griffith Centre for Coastal Management, Gold Coast campus, Griffith University, Gold Coast,

10 Queensland 4222, Australia.

11

$12{ }^{3}$ Miyazaki International College, Miyazaki, Japan.

13

14 Corresponding Author:

15 Leyton Tierney

16 C/o Environmental Futures Research Institute, Gold Coast campus, Griffith University, Gold

17 Coast, Queensland 4222, Australia.

18 Email address: leyton.tierney@griffithuni.edu.au 


\section{Abstract}

Cherax quadricarinatus has been widely translocated within Australia, and a number of selfsustaining feral populations have established, and persisted, in central-eastern Australia for over 20 years: however the biology and ecology of feral populations remain poorly understood. Using the loss-by-ignition method, this study investigated differences in the total content of incombustible material (as a proxy for total mineral content), between feral C. quadricarinatus populations in southeast Queensland and northeastern New South Wales.

One hundred and two C. quadricarinatus were ignited, and percent total incombustible material was not proportional to the body size, or gender of the crayfish. Incombustible content was however significantly different between some locations of capture (i.e. waterbodies). The site where incombustible content in crayfish was atypical, Lake Ainsworth, is a naturally acidic coastal lake, and we suggest that acidity and low concentration of calcium in that waterbody are likely responsible for the difference in mineral content detected in that population. Mechanism(s) driving the difference detected in the Lake Ainsworth population are unknown, but we suggest the acidic environment could directly impact maintenance of internal calcium reserves in the crayfish (inter-moult), during recalcification of the cuticle (postmoult), or both. Limited calcium availability in the Lake may also be a direct, or indirect contributing factor. The ability of $C$. quadricarinatus to occupy acidic habitats while managing biomineralisation challenges could possibly enable additional range-expansion of the species, and potential impacts on both endangered ecological communities, and other biota occupying the acidic coastal habitats of Eastern Australia. 


\section{Introduction}

52

Cherax quadricarinatus (von Martens) is one of 27 Australian species in the genus Cherax (additional species of Cherax are endemic to New Guinea)(Furse et al. 2015; Lukhaup, Eprilurahman \& von-Rintelen 2017). The native range of C. quadricarinatus covers the tropical north of Queensland (Qld) and Northern Territory, and the southern parts of New Guinea (Austin, Jones \& Wingfield 2010; Leland, Coughran \& Furse 2012; Riek 1969). Native range Extent of Occurrence (EOO, IUCN 2017) in Australia is $\sim 1.8$ million $\mathrm{km}^{2}$. The 2017 IUCN Red List status for C. quadricarinatus was Least Concern (Austin, Jones \& Wingfield 2010).

Cherax quadricarinatus is regarded as a hardy species, known to be tolerant of a broad range of environmental conditions (Leland, Coughran \& Furse 2012), e.g. low oxygen levels, high temperatures and salinity (Saoud, Garza De Yta \& Ghanawi 2012; Wingfield 2002), and these are likely typical conditions over much of its native northern Australian distribution (Jones 1989).

The species' native Australian range is characterized by distinct wet-dry seasons (the monsoon peak of the northern Australia wet season is December-March, BOM 2017c), warm average temperatures year-round, with high air temperatures in summer: daily maxima $>45^{\circ} \mathrm{C}$ (BOM 2017a). Northern Australia is also subject to periodic severe weather events including drought, heat waves and tropical cyclones. The native-range waterbodies occupied by C. quadricarinatus 
may be ephemeral, and inhabited by large predatory fish (e.g. Lates calcarifer (Bloch 1790)) and various Crocodylus species (including Crocodylus johnsoni Krefft 1873, Crocodylus novaeguineae (Schmidt, 1928) and Crocodylus porosus Schneider 1801). Overall the native range of C. quadricarinatus is a challenging environment for aquatic species.

Movements of the species, well outside of its natural distribution, are due to its desirable biological characteristics, and aesthetics, making it well suited to aquaculture (Lawrence \& Jones 2002), research, the aquarium trade (Furse et al. 2015), and as a recreational fisheries target. Cherax quadricarinatus has been translocated both within Qld and to other regions of Australia (Western Australia and New South Wales (NSW)) for aquaculture, and illegally as a species for recreational fishing (Doupé 2007; Doupé et al. 2004; Furse et al. 2015; Leland, Coughran \& Furse 2012). Additionally, the species has been translocated to more than 30 countries elsewhere, in regions including Africa, Asia, North America, Central America and Caribbean, South America, Europe and Oceania (see list in Furse et al. 2015), and in a number of these cases the species has established feral populations (e.g. South Africa and Swaziland, Spain, Singapore, Mexico, Malaysia: Belle et al. 2011; Gozlan 2010; Naiqiddin et al. 2016; Nakata \& Goshima 2003; Nunes et al. 2017; Petersen et al. 2017; Vega-Villasante et al. 2015).

While $C$. quadricarinatus is native to the tropics, successful aquaculture operations and feral populations have established, and been maintained, in Australia, south of the Tropic of Capricorn $\left(\sim 23.40^{\circ} \mathrm{S}\right)$, and even further south into a montane area, with temperate climate, in southeast Qld. The southernmost extent of the species' contemporary Australian distribution is Lake Ainsworth (NSW) at $28.78^{\circ} \mathrm{S}$ where a large feral population persists (Leland, Coughran \& Furse 2012). 
93

94

95

96

97

98

99

100

101

102

103

104

105

106

107

108

109

110

111

112

113

114

115

Cherax quadricarinatus is the world's most intensively studied species of freshwater crayfish, but despite the body of knowledge on captive biology, physiology, and aquaculture husbandry and production, the wild biology and ecology of the species remains poorly understood (Furse et al. 2015).

The species' ability to tolerate the at-times challenging environmental conditions within its native range, evidently provides this species with the capacity, and considerable opportunity to occupy the extensive and rather less environmentally challenging waterbodies elsewhere in Australia. Sufficient evidence is available to conclude that populations of this species are able to survive, and in some cases prosper, in atypical habitats and environmental conditions well outside its native range, in Australia and elsewhere. Populations occupy municipal water reservoirs in areas of temperate-climate, the subtropics and tropics (in both Hemispheres, e.g. Ahyong \& Yeo 2007), acidic coastal lakes in central-eastern Australia (Leland, Coughran \& Furse 2012), and waterbodies in the semi-arid zone of Australia (JM Furse unpublished data 2014). However, it is not known if occupying these atypical habitats has any biological or physical impact(s) on C. quadricarinatus. 8

Cherax quadricarinatus is an ecologically aggressive species (Furse et al. 2015; Furse \& Coughran 2011) and one consequence of escapees, or intentional releases, is that this species will establish and naturalise in many locations where it is likely to present a risk of disrupting/displacing the local fauna (James et al. 2015; Leland, Coughran \& Furse 2012; Papavlasopoulou et al. 2013). In particular this may threaten other species (including endangered species)(Furse \& Coughran 2011; Leland, Coughran \& Furse 2012; Richman et al. 2015), but can also cause damage to key or threatened habitats (Horwitz 1990; James et al. 2015). 
116 Freshwater crayfish are keystone species (e.g. Momot 1995) and capable ecosystem engineers

117 (Creed \& Reed 2004; Statzner et al. 2000; Statzner, Peltret \& Tomanova 2003). Therefore, 118 consequences of impacts caused by ongoing introductions, or spread, of C. quadricarinatus 119 through waterways could be appreciable.

121 Specimens captured during a previous (2014) and unrelated distributional study of feral $C$. 122 quadricarinatus populations in southeast Qld and northern NSW (JM Furse et al. unpublished 123 data) presented an opportunity to investigate any differences between populations in distinctly 124 atypical habitats.

126 The objective of this study was to determine if the total content of incombustible material in $C$. 127 quadricarinatus differed between feral populations occupying different waterbodies within the 128 study area.

\section{Materials \&Methods}

131

132

133

134

135

136

137

138

\section{Collection and Storage of Crayfish}

Crayfish were collected during a study over the Austral Summer-Autumn of 2014 (JanuaryApril). Thirty locations (i.e. waterbodies) were surveyed in southeast Qld and northeastern NSW, and crayfish were collected from 5 different waterbodies. The 30 waterbodies were selected for survey on the basis that self-sustaining feral populations of the species were known to have established there, or the species may have established there via translocation, migration through waterways, or overland movement. Crayfish were collected using a standardized trapping protocol (employing baited box traps, also called 'bait' or 'shrimp' traps, dimensions $250 \mathrm{~mm} \times$ 
$139250 \mathrm{~mm} \times 370 \mathrm{~mm}, 75 \mathrm{~mm}$ entrance apertures, $\sim 2 \mathrm{~mm}$ mesh) that was applied at all locations.

140 Trapping was primarily conducted in the morning (0630-1000) and afternoon (1300-1800), with

141 a few late-evening and overnight sets deployed. Single measurements of water temperature, and $142 \mathrm{pH}$ were recorded at time-of-capture, at all locations (Hanna Instruments ${ }^{\circledR}$, HI 98129, $143 \mathrm{pH} /$ Conductivity/TDS Tester, Woonsocket, Rhode Island, USA). Crayfish were collected under 144 NSW Department of Primary Industries Fisheries Section 37 Permit P12/0026-2.0 and Qld 145 Fisheries General Fisheries Permit 169932.

146 Long-term data were obtained from water supply authorities, or literature, for the following 147 parameters: water temperature, $\mathrm{pH}$, total hardness (as $\mathrm{CaCO}_{3}, \mathrm{NHMRC-NRMMC} \mathrm{2011),} \mathrm{total}$ 148 alkalinity, and calcium and magnesium concentrations. These data covered capture dates of all 149 crayfish in this study (except Lake Ainsworth), and in some cases covered the likely lifespan (i.e. $150 \quad 4-5$ years) of those crayfish.

151

152 Following capture, crayfish were measured (Occipital-Carapace length)(OCL, Morgan 1997), 153 and gender (male, female or indeterminate) was assessed by examination of external 154 reproductive structures. Crayfish were placed in plastic Ziplock ${ }^{\circledR}$ bags, stored under refrigeration 155 in the field, before being transported to the laboratory for euthanasia by freezing and subsequent 156 frozen storage.

Laboratory Procedure

159 The percent total incombustible content of crayfish was determined using the Ash Content 160 method of Allen et al. (1974). 
161 Crayfish were thawed at room temperature $\left(\sim 21^{\circ} \mathrm{C}\right)$, and whole crayfish were dried to constant

162 weight at $100^{\circ} \mathrm{C}$, pre-weighed to the nearest $0.0001 \mathrm{~g}$ (AND HR-300 analytical balance) and

163 subsequently ground to a fine powder in a domestic coffee grinder (Sunbeam MultiGrinder II).

164 Wherever possible the entire powdered crayfish were ignited (in pre-weighed crucibles), or in the

165 case of the larger specimens: subsamples (average weight of subsample $\sim 6.5 \mathrm{~g}$ ). All powdered

166 crayfish or subsamples were ignited for 1 hour at $500^{\circ} \mathrm{C}$ in an electric muffle furnace, cooled in a

167 desiccator for 30 minutes before being weighed again. Following final weighing, all ignited

168 samples were examined for any evidence of incomplete combustion (as per Allen et al. 1974).

169 The ash residue of the ignited samples included all incombustible residues i.e. minerals,

170 including metals, and other elements present in the crayfish, plus any uncombusted organic

171 material bound within inorganic matrices, and hereafter is collectively considered as a proxy

172 measure of the mineral content of the samples. The percent dry weight (DWT) total

173 incombustible material (hereafter incombustible content) of each crayfish was determined by

174 calculation.

175

176

Data Analysis

177 Raw data were plotted (scatter and boxplots) and examined for obvious trends. Effects of gender

178 and location were assessed simultaneously by factorial ANOVA, and final analysis used a main

179 effects ANOVA with gender, OCL and location as factors. A post-hoc Tukey's LSD provided $p$ -

180 values for differences between locations. All analysis were performed using STATISTICA for

181 Windows (Version 7.1)(StatSoft Inc 2005), critical value for $\alpha$ was 0.05 throughout. Long-term

182 water temperature and water chemistry data were tabulated to show any differences between 183 locations. 


\section{Results}

186

Crayfish were collected, at all times of the day, from waterbodies within the subtropical climate zone, a temperate-classified area of central-eastern Australia (climate zones based on a modified Koppen system, BOM 2017b), with four of the collection locations being large municipal water reservoirs on basaltic strata, and one (Lake Ainsworth) a perched coastal dune lake underlain by siliceous sand deposits (Timms 1982). Well-established biotic communities were evident at all locations, and included: algae, macrophytes, invertebrates and vertebrates (fishes, reptiles, birds): typically, crustacean zooplankter's were highly abundant.

One hundred and two crayfish were collected from the 5 locations (Table 1), processed and ignited: 58 females, 43 males and 1 case where gender could not be assigned. The case where gender could not be assigned was excluded from statistical analysis including gender as a factor. All crayfish were captured in fully-calcified (i.e. intermoult) condition, both clean and very dirty exoskeletons were noted, indicating recent moult activity, or otherwise.

\section{Water temperature and $\mathrm{pH}$ at time of capture differed between locations of capture (Table 1). On} average, long-term water temperatures were similar between locations, but some differences in water chemistries were evident between locations (principally $\mathrm{pH}$, total hardness, calcium and magnesium (Table 2). Water chemistries at Lake Ainsworth and Emigrant Creek Dam were comparable, but Emigrant Creek Dam had, on average, the lowest values in this study for hardness $\left(16.70 \mathrm{mg} \mathrm{L}^{-1}\right)$ and magnesium $\left(2.30 \mathrm{mg} \mathrm{L}^{-1}\right)$. On average, Lake Ainsworth had the 
206 lowest values for $\mathrm{pH}(5.91)$ and calcium $\left(2.21 \mathrm{mg} \mathrm{L}^{-1}\right)$, and hardness $\left(22.76 \mathrm{mg} \mathrm{L}^{-1}\right)$ was

207 substantially lower than both Lakes Moogerah (86.60 $\left.\mathrm{mg} \mathrm{L}^{-1}\right)$ and Somerset $\left(50.31 \mathrm{mg} \mathrm{l}^{-1}\right)$.

208 A histogram of the raw incombustible content indicated a slight positive skew. A $\log (\mathrm{x})$

209 transformation was applied and rendered the distribution of the data approximately normal.

210 Percent incombustible content of crayfish plotted versus OCL (Figure 1) showed a weak, non-

211 significant positive correlation $\left(\mathrm{R}^{2}=0.027, \mathrm{p}=0.10\right)$, indicating that correction for OCL was not

212 required for subsequent analysis. There was no significant difference in incombustible content

213 between gender $(\mathrm{p}=0.39)$. The gender*location interaction term was also not significant

$214(p=0.97)$, but location of capture was significant $\left(p=8.0 \times 10^{-8}\right)$, all by 2 -way factorial ANOVA.

215 A boxplot of percent incombustible content by location of capture indicated which locations

216 differed (Figure 2). The wider 95\% confidence intervals for the Lake Moogerah data can be

217 attributed to the natural variation (13\% difference) of incombustible content in the smaller $(\mathrm{N}=2)$

218 sample size at that location, however these data did not unduly influence, or leverage, any

219 subsequent statistical analysis. A LSD post hoc test indicated Lake Ainsworth as significantly

220 different to Emigrant Creek Dam and Lake Somerset ( $\mathrm{p}=0.0031$ and $\mathrm{p}=5.0 \times 10^{-7}$ respectively).

221 Incombustible content did not differ significantly between any other locations.

222

\section{Discussion}

224 This study advances our understanding of wild populations of C. quadricarinatus within

225 Australia, and information uncovered in this study is relevant to both the on-going translocations

226 (and spread) of this species within Australia, but also in other regions elsewhere in the World.

227 It is well established that $C$. quadricarinatus is a 'tough' species of freshwater crayfish (see

228 review in Furse et al. 2015), tolerant of environmental extremes. However, the present study has 
229

230

231

232

233

234

235

236

237

238

239

240

241

242

243

244

245

246

247

248

249

250

uncovered a new dimension of the capacity of $C$. quadricarinatus to cope with challenging environmental conditions. In this case crayfish were collected from established, self-sustaining populations that have persisted well outside this species' native-range for more than 6 years (e.g. Lake Ainsworth) and over 20 years in the case of Lake Somerset. Similarly, all waterbodies supporting these populations were distinctly non-native habitat-types located in non-native climatic zones (e.g. temperate-to- subtropical climates)(Modified Koppen classification, BOM 2017b).

Water chemistry data indicated the waterbodies 'grouped' in two categories: locations in NSW with lower $\mathrm{pH}$ and hardness, and locations in Qld with neutral $\mathrm{pH}$ and considerably higher hardness. Similarities in water chemistries between Lake Ainsworth and Emigrant Creek Dam may, in part, be attributable to that region's somewhat uniform basaltic geology, and both locations being situated in the same catchment, $\sim 7 \mathrm{~km}$ apart.

While it has been previously reported that C. quadricarinatus can occupy acidic environments (e.g. Leland, Coughran \& Furse 2012, Lake Ainsworth: a naturally acidic coastal window lake, Timms 1982), any long-term physical/physiological impact(s) of this species occupying such habitat are not well documented. This study establishes that there is a demonstrated physical impact on $C$. quadricarinatus occupying acidic habitat, in this case a significantly lower total incombustible-mineral content compared to crayfish collected from other non-acidic habitats. In this case we presume the incombustible content was primarily composed of calcareous minerals derived from the crayfish exoskeletons and tissues, and any other residues (e.g. other metals and incombustible non-metals) were at negligible levels (sensu Jussila, Henttonen \& Huner 1995). 
252 Despite acidic conditions, and in particular, having to maintain a calcified exoskeleton (i.e.

253 internal stores of calcium) in adverse conditions, this study supports a conclusion that

254 populations of $C$. quadricarinatus can persist, and evidently prosper, medium-to long-term in

255 acidic habitats, including where calcium is not abundant. An alternative interpretation is that this

256 study has uncovered evidence establishing the C. quadricarinatus at Lake Ainsworth are not

257 actually coping with the $\mathrm{pH}$ and low mineral availability, and the population is under-

258 mineralised. This alternative explanation seems less likely given that C. quadricarinatus has

259 prospered and remained so abundant in Lake Ainsworth for nearly a decade.

Other Australian Cherax are known to occupy acidic habitats, e.g. Cherax cuspidatus Riek (Lake

Ainsworth, native range-and habitat)(see Leland, Coughran \& Furse 2012), and Cherax cainii

Austin and Ryan (formerly Cherax tenuimanus (Smith))(old mining pits, native range, nonnative habitat) where mild stress due to acid exposure was reported (Storer, Whisson \& Evans 2002).

The exact mechanism driving the lower incombustible content in the Lake Ainsworth population

267 (or conversely the higher incombustible content in other waterbodies) in this study is unclear, but given the acidic condition of Lake Ainsworth, we speculate it is possible that acidity is a factor directly, or indirectly, contributing to the differences reported here.

Biomineralization is a reasonably well-understood phenomenon in the Crustacea, and freshwater crayfish, so some speculation that effect(s) of an acidic environment may occur in $C$. quadricarinatus is appropriate. However, we hypothesize that the water chemistry of Lake 
275 The mineral that is principally responsible for providing rigidity and strength to the structure of

276 the exoskeleton in freshwater crayfish is calcium carbonate $\left(\mathrm{CaCO}_{3}\right)($ Huner, Kowalczuk \&

277 Avault 1978; Reynolds 2002). Calcium is therefore one of the key elements for growth in

278 freshwater crayfish (Reynolds 2002): especially so postmoult (Greenaway 1985; Huner,

279 Kowalczuk \& Avault 1978). Postmoult, part of the mineral requirement for recalcifying the new

280 cuticle is met by retaining calcium from the previous exoskeleton (via storage in the gastroliths

281 located in the foregut, formed pre-moult) with the remainder derived from the water column,

282 food, or other ingested material such as the exuvium (Adegboye, Hagadorn \& Hirsch 1975;

283 Greenaway 1985).

284

285 Calcareous minerals are a key structural component of crustacean exoskeletons (e.g. Bentov et 286 al. 2012), and the acidity of Lake Ainsworth (the most acidic in the study) has the potential to 287 directly (and indirectly) influence calcareous mineral content in the population of $C$. 288 quadricarinatus. The acidity of the Lake may directly influence, via increased solubility, internal 289 calcareous mineral content premoult (i.e. during decalcification and gastrolith formation), but 290 also postmoult, during both recalcification from internal stores i.e. solubilisation and 291 reabsorption of gastrolith calcium) and uptake from external sources of calcium. Availability of 292 bicarbonate $\left(\mathrm{HCO}_{3}^{-}\right)$is reduced in acidic conditions and if insufficient bicarbonate is available 293 from internal sources, this may also directly contribute to reduced internal calcareous mineral 294 content.

295 It is therefore possible the $\mathrm{pH}$ of Lake Ainsworth is, at times, simply outside of the biologically296 tolerable range where C. quadricarinatus is able to calcify, or maintain calcification. 
298 Water chemistry data indicates Lake Ainsworth is not a calcium-rich environment, and limited 299 calcium availability may directly influence the mineral content of $C$. quadricarinatus in the lake.

300 Lower calcium availability may also interact with acidity of the lake, possibly indirectly creating 301 a limiting condition (i.e. Reynolds 2002), or becoming a limiting factor. One possible scenario 302 would be the acidity of Lake Ainsworth (i.e. reduced carbonate availability), interacting with the 303 low calcium levels thus limiting availability of both the components of calcium carbonate. While 304 water chemistry provides potential explanations for the difference in total mineral content, 305 assessed via incombustible content, at Lake Ainsworth, it is possible other unknown (and unmeasured) biotic and/or abiotic factors may be responsible.

It is not possible to determine why incombustible content in the crayfish from Emigrant Creek Dam was significantly higher than Lake Ainsworth despite lower hardness at that location. We speculate that the higher $\mathrm{pH}$ and calcium values, and lower magnesium value, at Emigrant Creek Dam may potentially negate any effect of the lower hardness.

312 Irrespective of the mechanism, the results reported here are consistent with those of others

313 workers reviewing (e.g. France 1983; France 1987; Greenaway 1985) or investigating physical, 314 or growth-or weight-related impacts of acidic environments on freshwater crayfish (e.g. France 3151983 pH 5.35; France 1987 pH 5.4 - 5.6; Haddaway et al. 2013 pH 6.5, 7.1 and 8.6; Malley 1980 316 pH 4.0 - 6.7; Yue et al. 2009 pH 6.8).

Increasing atmospheric $\mathrm{CO}_{2}$ may increase acidity in the acidic habitats of Eastern Australia, potentially impact rare and endangered native crayfish (Cherax and Tenuibranchiurus spp.) (e.g.

320 Beaune et al. 2018), but also feral populations of C. quadricarinatus in those habitats. Ongoing 
321 surveys and monitoring of these feral C. quadricarinatus populations may track any changes in

322 the distribution of $C$. quadricarinatus but may also permit the mechanism(s) driving the

323 differences in incombustible-mineral content reported here to be investigated and documented, in

324 particular any effects of Lake Ainsworth water chemistry on the mineralization and calcareous

325 content of C. quadricarinatus.

326

327

Potential Management Implications

328 We speculate that the ability of $C$. quadricarinatus populations to establish and survive, and 329 maintain internal calcium levels, in calcium-poor and acidic conditions, could have important 330 management implications. For instance, the substantial resident population of C. quadricarinatus 331 in the calcium-poor Lake Ainsworth, need to somehow obtain the calcium (sensu Adegboye, 332 Hagadorn \& Hirsch 1975) necessary for maintaining adequate internal levels. Other biota 333 occupying the lake, especially calcified biota (i.e. other native crayfish), are likely be an 334 accessible and useful source of calcium for C. quadricarinatus occupying the Lake.

335 Leland, Coughran \& Furse (2012) reported the smaller and ubiquitous C. cuspidatus appeared to 336 be absent in the lake, but not from the adjacent, acidic, Melaleuca quinquenervia swamps and 337 associated roadside drains. Monitoring of the adjacent habitats by the authors confirms that 338 situation remains unchanged and while C. cuspidatus is present, C. quadricarinatus has not been 339 detected in these nearby acidic habitats. It is unclear if $C$. quadricarinatus is involved in the 340 apparent absence of $C$. cuspidatus from the Lake, but it is reasonable to suggest the smaller 341 native crayfish (and other calcified biota) have been a relatively available and useful source of 342 calcareous minerals for the larger C. quadricarinatus, via predation and consumption. 
344 Eastern Australia's extensive acidic coastal Melaleuca swamps extend, discontinuously, from the

345 north of Queensland to Sydney in the south, and includes a number of coastal window lakes

346 similar to Lake Ainsworth. These acidic coastal swamps and lakes are occupied by other rare

347 and/or critically endangered species (including other species of crayfish: Tenuibranchiurus spp.

348 Coughran, Dawkins \& Furse 2010; Dawkins et al. 2010; Dawkins et al. 2017), and include

349 endangered ecological communities (e.g. freshwater wetlands on coastal floodplains in NSW). It

350 is possible the ability of $C$. quadricarinatus to occupy and survive in these acidic habitats could

351 potentially lead to direct, or indirect, negative impacts on the various rare and endangered native

352 floral and faunal species in these habitats.

354 Similarly, while not continuous, the coastal swamps of eastern Australia could potentially act as 355 an "invasion" route that $C$. quadricarinatus could exploit, possibly providing an otherwise 356 unavailable pathway $600 \mathrm{~km}$ south, or $>1500 \mathrm{~km}$ to the north and west (adjacent the species 357 native range).

359 Limitations of Study

360 Loss-by-ignition residues may include non-targets (e.g. metals and other incombustible

361 elements) and possible small traces of uncombusted organic material, and this presumably 362 applies to the incombustible material data obtained in this study. Analysis of mineral content, or 363 other constituents of the combustion residues, was not possible in this study, however it is 364 reasonable to assume residues were principally mineral, and any other incombustible non365 minerals were minor components (e.g. Bryan 1967; Jussila, Henttonen \& Huner 1995). 366 Therefore, our standard method, applied to all samples, has resulted in a consistent measure of 
367 actual minerals, plus all non-targets, in all samples. Although numbers of crayfish collected from

368 some locations were small $(\mathrm{N}<20)$, most 95\% confidence intervals (C.I.) were tight and the

369 effects of location of capture on incombustible content were strong. As previously outlined, the

370 broader $95 \%$ C.I. at Lakes Moogerah and Dyer are attributable to natural variation in the

371 incombustible content in the crayfish captured there (13\% and $1.6 \%$ respectively): results need to

372 be interpreted accordingly until the mineral content in these populations has been investigated 373 and clarified.

Recent water chemistry data, for the parameters of interest in this study, do not exist for Lake Ainsworth; the historical water chemistry data available to us did however permit satisfactory characterization of the lakes water chemistry, in particular: establishing low $\mathrm{CaCO}_{3}$ and $\mathrm{Calcium}$ concentrations, and persistent acidic conditions. The 1987 Lake Ainsworth maximum, average and median values for $\mathrm{CaCO}_{3}$ and Calcium indicated high-value induced skew, but as values for $\mathrm{CaCO}_{3}$ and Calcium in the 1996 data were unremarkable, we drew on the 1996 data.

\section{Conclusions}

The incombustible content of feral $C$. quadricarinatus populations differed significantly between the locations in this study, and the low total mineral content (using incombustible material as a mineral-content proxy) in crayfish from Lake Ainsworth is likely attributable to the lake's $\mathrm{pH}$ and limited calcium availability. This study supports other findings that C. quadricarinatus is tolerant of environments that are acidic, but also calcium-poor, and additionally demonstrates that despite these conditions the species can evidently prosper, albeit with some physical impact. 
390 This opens the possibility of the species having the potential to occupy the extensive coastal

391 swamps of central-eastern Australia, with possible implications for the resident endemic flora 392 and fauna.

393

394 Acknowledgements

395 The study was conducted as $3^{\text {rd }}$ year Undergraduate Project by Leyton J. Tierney under the 396 supervision of James M. Furse and Clyde H. Wild. Many thanks to Patrick Plunkett (NSW DPI 397 Fisheries Officer) for accommodating our numerous and on-going trapping activities in Lake 398 Ainsworth and environs. Shane Norman Patrick Archibald-Howard kindly facilitated access to 399 some water chemistry data. Thanks are extended to the following for kindly providing historical 400 water chemistry data: Stuart Hood (Rous County Council, NSW, Emigrant Creek Dam), Ballina 401 402 403 reviewers.

\section{References}

Adegboye JD, Hagadorn IR, and Hirsch PF. 1975. Variations in hemolymph calcium associated 
411 Ahyong ST, and Yeo DCJ. 2007. Feral populations of the Australian Red-Claw crayfish (Cherax

412 quadricarinatus von Martens) in water supply catchments of Singapore. Biological

$413 \quad$ Invasions 9:943-946.

414 Allen SE, Grimshaw HM, Parkinson JA, and Quarmby C. 1974. Chemical Analysis of Ecological 415 Materials. Oxford, England.: Blackwell Scientific Publications.

416 Austin CM, Jones C, and Wingfield M. 2010. Cherax quadricarinatus. In: IUCN Red List of 417 Threatened Species (Version 2011.1). The International Union for Conservation of Nature and Natural Resources. Gland, Switzerland. p 2

419 Beaune D, Sellier Y, Luquet G, and Grandjean F. 2018. Freshwater acidification: an example of an endangered crayfish species sensitive to $\mathrm{pH}$. Hydrobiologia

422 https://doi.org/10.1007/s10750-018-3504-4.

Belle CC, Wong JQH, Yeo DCJ, Tan SH, Tan HH, Clews E, and Todd PA. 2011. Ornamental trade as a pathway for Australian redclaw crayfish introduction and establishment. Aquatic Biology 12:69-79.

Bentov S, Zaslansky P, Al-Sawalmih A, Masic A, Fratzl P, Sagi A, Berman A, and Aichmayer B. 2012. Enamel-like apatite crown covering amorphous mineral in a crayfish mandible. Nature Communications 3:DOI:10.1038/ncomms1839.

BOM. 2017a. Average daily temperatures. Available at Australian Government, Bureau of Meteorology, Commonwealth of Australia, Canberra, Australia. Available online via: http://www.bom.gov.au/jsp/ncc/climate averages/temperature/index.jsp? maptype=1\&perio $\underline{d=a n \# \text { maps }}$.

BOM. 2017b. Climate Classification Maps. Available at Australian Government, Bureau of 433 Meteorology, Commonwealth of Australia, Canberra, Australia. Available online via: 
434

435

436

437

438

439

440

441

442

443

444

445

446

447

448

449

450

451

452

453

454

455

456

\section{http://www.bom.gov.au/jsp/ncc/climate averages/climate-}

classifications/index.jsp? maptype $=$ kpngrp\#maps.

BOM. 2017c. Climate Glossary, Monsoon. Available at Australian Government, Bureau of Meteorology, Commonwealth of Australia, Canberra, Australia. Available online via: http://www.bom.gov.au/climate/glossary/monsoon.shtml.

Bryan GW. 1967. Zinc Regulation in the Freshwater Crayfish (Including Some Comparative Copper Analyses). Journal of Experimental Biology 46:281-296.

Coughran J, Dawkins KL, and Furse JM. 2010. Tenuibranchiurus glypticus. In: IUCN 2013. IUCN Red List of Threatened Species. Version 2012.2. The International Union for Conservation of Nature and Natural Resources. Gland, Switzerland. p 3.

Creed RP, Jr, and Reed JM. 2004. Ecosystem engineering by crayfish in a headwater stream community. Journal of the North American Benthological Society 23:224-236.

Dawkins KL, Furse JM, Wild CH, and Hughes JM. 2010. Distribution and population genetics of the threatened freshwater crayfish genus Tenuibranchiurus (Decapoda: Parastacidae). Marine and Freshwater Research 61:1048-1055.

Dawkins KL, Furse JM, Wild CH, and Hughes JM. 2017. A novel genus and cryptic species harboured within the monotypic freshwater crayfish genus Tenuibranchiurus Riek, 1951 (Decapoda: Parastacidae). PeerJ 5:e3310; DOI 10.7717/peerj.3310:1-24.

Doupé RG. 2007. Where are they now? A baseline distributional description of introduced redclaw crayfish Cherax quadricarinatus (von Martens) in the east Kimberley region. Journal of the Royal Society of Western Australia 90:215-218.

Doupé RG, Morgan DL, Gill HS, and Rowland AJ. 2004. Introduction of redclaw crayfish Cherax quadricarinatus (von Martens) to Lake Kununurra, Ord River, Western Australia: 
457

458

459

460

461

462

463

464

465

466

467

468

469

470

471

472

473

474

475

476

477

478

479

prospects for a 'yabby' in the Kimberley. Journal of the Royal Society of Western Australia 87:187-191.

France RL. 1983. The response of the crayfish Orconectes virilis to experimental acidification of a Lake with special reference to the importance of calcium. Freshwater Crayfish 5:98-111.

France RL. 1987. Calcium and Trace Metal Composition of Crayfish (Orconectes virilis) in Relation to Experimental Lake Acidification. Canadian Journal of Fisheries \& Aquatic Sciences 44:107-113.

Furse JM, Burnham QF, Dawkins KL, and Richardson AMM. 2015. Chapter 20: Oceania: The Freshwater Crayfish of the Oceania Region. In: Kawai T, Faulkes Z, and Scholtz G, eds. Freshwater Crayfish: A Global Overview Section 3: Global overview of freshwater crayfish biology. Boca Raton, Florida, USA: CRC Press, 485-582.

Furse JM, and Coughran J. 2011. An assessment of the distribution, biology, threatening processes and conservation status of the freshwater crayfish, genus Euastacus (Decapoda: Parastacidae), in Continental Australia. II. Threats, Conservation Assessments and Key Findings. Crustaceana Monographs 15 (Special edition: New Frontiers in Crustacean Biology):253-263.

Gozlan RE. 2010. The cost of non-native aquatic species introductions in Spain: fact or fiction? Aquatic Invasions 5:231-238.

Greenaway P. 1985. Calcium balance and moulting in the Crustacea. Biological Reviews $60: 425-454$.

Haddaway NR, Mortimer RGJ, Christmas M, and Dunn AM. 2013. Effect of pH on growth and survival in the freshwater crayfish Austropotamobius pallipes. Freshwater Crayfish 19:5362. 
480 481

482 483

484

485

486

487

488

489

490

491

492

493

494

495

496

497

498

499

500

501

502

Horwitz P. 1990. The translocation of freshwater crayfish in Australia: potential impact, the need for control and global relevance. Biological Conservation 54:291-305.

Huner JV, Kowalczuk JG, and Avault JW, Jr,. 1978. Postmolt Calcification in Subadult Red Swamp Crayfish, Procambarus clarkii (Girard) (Decapoda, Cambaridae). Crustaceana $34: 275-280$

IUCN. 2017. Guidelines for Using the IUCN Red List Categories and Criteria: Version 13. Gland, Switzerland and Cambridge, UK: Prepared by the Standards and Petitions Subcommittee of the IUCN Species Survival Commission. p 108.

James J, Slater F, Vaughan I, Young K, and Cable J. 2015. Comparing the ecological impacts of native and invasive crayfish: could native species' translocation do more harm than good? Oecologia 178:309-316. DOI 310.1007/s00442-00014-03195-00440.

Jones CM. 1989. The Biology and Aquaculture Potential of The Tropical Freshwater Crayfish Cherax quadricarinatus. Project No. QDPI/8860. Walkamin, Queensland, Australia: Queensland Department of Primary Industries, Fisheries Branch Research Station. p 130.

Jussila J, Henttonen P, and Huner JV. 1995. Calcium, magnesium, and manganese content of noble crayfish Astacus astacus (L.)) branchial carapace and its relationship to water and sediment mineral contents of two ponds and one lake in central Finland. Freshwater Crayfish 10:230-238.

Lawrence C, and Jones C. 2002. Crayfish of commercial importance: Cherax. In: Holdich DM, ed. Biology of Freshwater Crayfish. Oxford, England: Blackwell Science, 635-666.

Leland JC, Coughran J, and Furse JM. 2012. Further translocation of the Redclaw, Cherax quadricarinatus (Decapoda: Parastacidae), to Lake Ainsworth in northeastern New South Wales, Australia. Crustacean Research Special Number 7:1-4. 
503 Lukhaup C, Eprilurahman R, and von-Rintelen T. 2017. Cherax warsamsonicus, a new species

504 of crayfish from the Kepala Burung (Vogelkop) peninsula in West Papua, Indonesia

505 (Crustacea, Decapoda, Parastacidae). Zookeys 660:151-167.

506 https://doi.org/110.3897/zookeys.3660.11847.

507 Malley DF. 1980. Decreased Survival and Calcium Uptake by the Crayfish Orconectes virilis in

$508 \quad$ Low pH. Canadian Journal of Fisheries \& Aquatic Sciences 37:364-372.

509 Momot WT. 1995. Redefining the role of crayfish in aquatic ecosystems. Reviews in Fisheries

$510 \quad$ Science 3:33-63.

511 Morgan GJ. 1997. Freshwater crayfish of the genus Euastacus Clark (Decapoda: Parastacidae)

512 from New South Wales, with a key to all species of the genus. Records of the Australian

$513 \quad$ Museum Supplement 23:110.

514 Naiqiddin AS, Rahim KAA, Long SM, and Firdaus FF. 2016. The Spread of the Australian

515 Redclaw Crayfish (Cherax quadricarinatus von Martens, 1868) in Malaysia. Journal of

$516 \quad$ Sustainability Science and Management 11:31-38.

517 Nakata K, and Goshima S. 2003. Competition for shelter of preferred sizes between the native

518 crayfish species Cambaroides japonicus and the alien crayfish species Pacifastacus

519 leniusculus in Japan in relation to prior residence, sex difference and body size. Journal of

$520 \quad$ Crustacean Biology 23:897-907.

521 NHMRC-NRMMC. 2011. Australian Drinking Water Guidelines (ADWG) - Hardness. National

522 Health and Medical Research Council, National Resource Management Ministerial Council, 523 Commonwealth of Australia, Canberra, ACT, Australia. p 868-687. 
524 Nunes AL, Zengeya TA, Hoffman AC, Measey GJ, and Weyl OLF. 2017. Distribution and

525 establishment of the alien Australian redclaw crayfish, Cherax quadricarinatus, in South

$526 \quad$ Africa and Swaziland. PeerJ 5:e3135; DOI 10.7717/peerj.3135:1-21.

527 Papavlasopoulou I, Perdikaris C, Vardakas L, and Paschos I. 2013. Enemy at the gates:

528 introduction potential of non-indigenous freshwater crayfish in Greece via the aquarium

$529 \quad$ trade. Central European Journal of Biology 9:11-18.

530 Petersen RM, Hoffman AC, Kotze P, and Marr SM. 2017. First record of the invasive Australian

531 redclaw crayfish Cherax quadricarinatus (von Martens, 1868) in the Crocodile River,

532 Kruger National Park, South Africa. Koedoe 59:a1435. https:// doi.org/1410.4102/koedoe.

$533 \quad$ v1459i1431.1435.

534 Reynolds JD. 2002. General Biology: Growth and Reproduction. In: Holdich DM, ed. Biology of 535 Freshwater Crayfish. Oxford, England.: Blackwell Science, 152-191.

536 Richman NI, Böhm M, Adams SB, Alvarez F, Bergey EA, Bunn JJS, Burnham Q, Cordeiro J, 537 Coughran J, Crandall KA, Dawkins KL, DiStefano RJ, Doran NE, Edsman L, Eversole AG, 538 Füreder L, Furse JM, Gherardi F, Hamr P, Holdich DM, Horwitz P, Johnston K, Jones CM, 539 Jones JPG, Jones RL, Jones TG, Kawai T, Lawler S, López-Mejía M, Miller RM, Pedraza-

540 Lara C, Reynolds JD, Richardson AMM, Schultz MB, Schuster GA, Sibley PJ, Souty-

541 Grosset C, Taylor CA, Thoma RF, Walls J, Walsh TS, and Collen B. 2015. Multiple drivers

542 of decline in the global status of freshwater crayfish (Decapoda: Astacidea). Philosophical

543 Transactions of the Royal Society B: Biological Sciences 370: 20140060. DOI:

544 20140010.20141098/rstb.20142014.20140060.

Riek EF. 1969. The Australian freshwater crayfish (Crustacea: Decapoda: Parastacidae), with 546 descriptions of new species. Australian Journal of Zoology 17:855-918. 
547 Saoud IP, A Garza De Yta, and Ghanawi J. 2012. A review of nutritional biology and dietary

548 requirements of redclaw crayfish Cherax quadricarinatus (von Martens 1868). Aquaculture

$549 \quad$ Nutrition 18:349-368. 10.1111/j.1365-2095.2011.00925.x

550 StatSoft Inc. 2005. STATISTICA for Windows. Version 7.1 ed. Tulsa, Oklahoma, USA.

551 Statzner B, Fievet E, Champagne J-Y, Morel R, and Herouin E. 2000. Crayfish as geomorphic

552 agents and ecosystem engineers: Biological behavior affects sand and gravel erosion in

553 experimental streams. Limnology and Oceanography 45:1030-1040.

554 Statzner B, Peltret O, and Tomanova S. 2003. Crayfish as geomorphic agents and ecosystem

555 engineers: effect of a biomass gradient on baseflow and flood-induced transport of gravel

$556 \quad$ and sand in experimental streams. Freshwater Biology 48:147-163.

557 Storer TJ, Whisson GJ, and Evans LH. 2002. Seasonal variation in health and condition of

558 marron (Cherax tenuimanus) from acidic and non-acidic waterbodies in the Collie Basin,

$559 \quad$ Western Australia. Freshwater Crayfish 13:525-538.

560 Timms BV. 1982. Coastal Dune Waterbodies of North-eastern New South Wales. Australian

561 Journal of Marine and Freshwater Research 33:203-222.

562 Vega-Villasante F, Ávalos-Aguilar JJ, Nolasco-Soria H, Vargas-Ceballos MA, Bortolini-Rosales

563 JL, Chong-Carrillo O, Ruiz-Núñez MF, and Morales-Hernández JC. 2015. Wild populations

564 of the invasive Australian red claw crayfish Cherax quadricarinatus (Crustacea, Decapoda)

565 near the northern coast of Jalisco, Mexico: a new fishing and profitable resource. Latin

566 American Journal of Aquatic Research 43:781-785.

567 Wingfield M. 2002. An overview of the Australian freshwater crayfish farming industry.

$568 \quad$ Freshwater Crayfish 13:177-184. 
569 Yue CF, Wang TT, Wang YF, and Peng Y. 2009. Effect of combined photoperiod, water

570 calcium concentration and $\mathrm{pH}$ on survival, growth, and moulting of juvenile crayfish

571 (Procambarus clarkii) cultured under laboratory conditions. Aquaculture Research 40:1243-

$572 \quad 1250$.

573

574 


\section{Table $\mathbf{1}$ (on next page)}

Summary of capture locations, environmental conditions at time of capture, and crayfish captured in this study.

Refer Figure 2 for boxplot associated with percent DWT incombustible content mean and $\pm 95 \%$ Confidence Interval (C.I.) values reported here. 


\begin{tabular}{|c|c|c|c|c|c|c|}
\hline \multirow{2}{*}{\multicolumn{2}{|c|}{$\mathrm{N}=102$}} & \multicolumn{5}{|c|}{ Location of Capture } \\
\hline & & $\begin{array}{l}\text { Lake Ainsworth } \\
\text { (NSW) }\end{array}$ & $\begin{array}{l}\text { Lake Dyer } \\
\text { (Qld) }\end{array}$ & $\begin{array}{c}\text { Emigrant Creek } \\
\text { Dam } \\
(\mathrm{NSW})\end{array}$ & $\begin{array}{c}\text { Lake Moogerah } \\
\text { (Qld) }\end{array}$ & $\begin{array}{l}\text { Lake Somerset } \\
\text { (Qld) }\end{array}$ \\
\hline \multicolumn{2}{|c|}{ Coordinates } & $\begin{array}{c}28.783500^{\circ} \mathrm{S} \\
153.591852^{\circ} \mathrm{E} \\
\end{array}$ & $\begin{array}{r}27.628950^{\circ} \mathrm{S} \\
152.374936^{\circ} \mathrm{E}\end{array}$ & $\begin{array}{r}28.769090^{\circ} \mathrm{S} \\
153.517838^{\circ} \mathrm{E} \\
\end{array}$ & $\begin{array}{r}28.041717^{\circ} \mathrm{S} \\
152.551186^{\circ} \mathrm{E} \\
\end{array}$ & $\begin{array}{r}27.067288^{\circ} \mathrm{S} \\
152.588607^{\circ} \mathrm{E} \\
\end{array}$ \\
\hline \multicolumn{2}{|c|}{$\begin{array}{l}\text { Water Temperature }\left({ }^{\circ} \mathrm{C}\right) \\
\text { (at time of capture) }\end{array}$} & 28.5 & 25.4 & 24.4 & 31.7 & 27.1 \\
\hline \multicolumn{2}{|c|}{$\begin{array}{l}\mathrm{pH} \text { at Location of Capture } \\
\text { (time of measurement) }\end{array}$} & $\begin{array}{c}6.43 \\
(1428)\end{array}$ & $\begin{array}{c}8.80 \\
(1630)\end{array}$ & $\begin{array}{c}7.13 \\
(0905)\end{array}$ & $\begin{array}{c}8.91 \\
(1730)\end{array}$ & $\begin{array}{c}8.08 \\
(1000)\end{array}$ \\
\hline \multicolumn{2}{|c|}{ Total Number of Crayfish Captured } & 72 & 4 & 3 & 2 & 21 \\
\hline \multirow{2}{*}{ Gender } & Male:Female & $30: 42$ & $1: 3$ & $3: 0$ & $0: 2$ & $9: 11$ \\
\hline & Indeterminate & - & - & - & - & 1 \\
\hline \multirow{4}{*}{$\begin{array}{c}\text { OCL } \\
\text { (in } \mathrm{mm} \text { ) }\end{array}$} & Maximum & 64.22 & 50.13 & 59.79 & 60.51 & 67.41 \\
\hline & Average & 47.00 & 45.71 & 40.17 & 57.67 & 46.76 \\
\hline & Median & 46.37 & 45.81 & 52.51 & 57.67 & 44.98 \\
\hline & Minimum & 20.64 & 41.09 & 8.20 & 54.82 & 26.48 \\
\hline \multirow{3}{*}{$\begin{array}{c}\text { Percent DWT } \\
\text { Incombustible } \\
\text { Material } \\
\text { Mean and } \pm 95 \% \text { C.I. } \\
\text { Values (in g) }\end{array}$} & $\begin{array}{c}\text { Upper } 95 \% \\
\text { C.I. }\end{array}$ & 42.93 & 57.80 & 53.13 & 132.82 & 51.16 \\
\hline & Mean & 41.79 & 46.11 & 50.80 & 48.58 & 48.96 \\
\hline & $\begin{array}{c}\text { Lower } 95 \% \\
\text { C.I. }\end{array}$ & 40.66 & 31.42 & 48.47 & -35.66 & 46.77 \\
\hline
\end{tabular}




\section{Table 2 (on next page)}

Long-term water temperature and water chemistry data at locations of capture: average values highlighted in bold.

Data from Emigrant Creek Dam and Lake Somerset encompass the likely lifespan of the crayfish in this study. No data available for Lake Dyer. Unless otherwise stated, data provided by water supply authorities. 


\begin{tabular}{|c|c|c|c|c|c|c|c|}
\hline & & \multicolumn{6}{|c|}{ Location of Capture } \\
\hline & & $\begin{array}{c}\text { Lake } \\
\text { Ainsworth }^{\mathrm{A}} \\
(\mathrm{NSW})\end{array}$ & $\begin{array}{c}\text { Lake } \\
\text { Ainsworth }^{\mathrm{B}} \\
(\mathrm{NSW})\end{array}$ & $\begin{array}{l}\text { Lake Dyer } \\
\qquad \text { (Qld) }\end{array}$ & $\begin{array}{c}\text { Emigrant Creek } \\
\text { Dam (NSW) }\end{array}$ & $\begin{array}{l}\text { Lake Moogerah } \\
\text { (Qld) }\end{array}$ & $\begin{array}{c}\text { Lake Somerset } \\
\text { (Qld) }\end{array}$ \\
\hline \multirow{4}{*}{$\begin{array}{c}\text { Water } \\
\text { Temperature } \\
\left({ }^{\circ} \mathrm{C}\right)\end{array}$} & Maximum & - & 30.90 & - & 28.00 & 22.97 & 28.90 \\
\hline & Average & - & 23.70 & - & 20.90 & 22.50 & 21.56 \\
\hline & Median & - & 24.70 & - & 21.50 & 22.40 & 22.50 \\
\hline & Minimum & - & 14.90 & - & 13.30 & 22.04 & 13.70 \\
\hline \multirow{4}{*}{$\mathrm{pH}$} & Maximum & 9.40 & 8.00 & - & 9.60 & 7.75 & 8.40 \\
\hline & Average & 6.20 & 5.91 & - & 6.89 & 7.71 & 7.56 \\
\hline & Median & 6.20 & 5.81 & - & 6.90 & 7.72 & 7.50 \\
\hline & Minimum & 3.50 & 4.00 & - & 6.10 & 7.64 & 6.90 \\
\hline \multirow{4}{*}{$\begin{array}{c}\text { Total } \\
\text { Hardness } \\
\text { as } \mathrm{CaCO}_{3} \\
\left(\mathrm{mg} \mathrm{L}^{-1}\right)\end{array}$} & Maximum & 219.00 & 22.90 & - & 37.00 & 109.00 & 64.00 \\
\hline & Average & 35.24 & 22.76 & - & 16.70 & 86.60 & 50.31 \\
\hline & Median & 22.40 & 22.50 & - & 16.00 & 83.00 & 50.00 \\
\hline & Minimum & 5.99 & 22.10 & - & 6.00 & 64.00 & 28.00 \\
\hline \multirow{4}{*}{$\begin{array}{c}\text { Total } \\
\text { Alkalinity } \\
\text { as } \mathrm{CaCO}_{3} \\
\left(\mathrm{mg} \mathrm{L}^{-1}\right)\end{array}$} & Maximum & - & - & - & 39.00 & 101.00 & 78.00 \\
\hline & Average & - & - & - & 23.87 & 81.10 & 51.32 \\
\hline & Median & - & - & - & 23.00 & 78.50 & 52.00 \\
\hline & Minimum & - & - & - & 12.00 & 66.00 & 21.00 \\
\hline \multirow{4}{*}{$\begin{array}{l}\text { Calcium } \\
\left(\mathrm{mg} \mathrm{L}^{-1}\right)\end{array}$} & Maximum & 62.40 & 2.60 & - & 8.40 & - & 13.00 \\
\hline & Average & 14.2 & 2.21 & - & 2.97 & - & 9.23 \\
\hline & Median & 1.4 & 2.40 & - & 2.90 & - & 9.00 \\
\hline & Minimum & 0.6 & 0.80 & - & 1.00 & - & 5.50 \\
\hline \multirow{4}{*}{$\begin{array}{l}\text { Magnesium } \\
\left(\mathrm{mg} \mathrm{L}^{-1}\right)\end{array}$} & Maximum & 15.12 & 4.04 & - & 14.00 & - & 8.00 \\
\hline & Average & 3.96 & 4.20 & - & 2.30 & - & 6.12 \\
\hline & Median & 2.40 & 4.15 & - & 2.20 & - & 6.05 \\
\hline & Minimum & 1.08 & 4.87 & - & 0.90 & - & 3.50 \\
\hline
\end{tabular}

1 Lake Ainsworth ${ }^{\mathrm{A}}$, data from Timms 1987. Lake Ainsworth ${ }^{\mathrm{B}}$, data from Kadluczka, Howells \& van Senden 1996. 
2 Emigrant Creek Dam, weekly samples: January 2009 - May 2017.

3 Lake Moogerah, single values for Temperature, $\mathrm{pH}$ (March 2012), Hardness (November 2011), irregular monthly samples for 4 Alkalinity $(2011-2013)$.

5 Lake Somerset, weekly or monthly samples: February 2009 - May 2014 (Temperature: July 2011 - May 2014).

6 Note: Mean \& median values for $\mathrm{CaCO}_{3}$ and $\mathrm{Calcium}$ in Ainsworth ${ }^{\mathrm{A}}$ data indicate high-value outlier-induced skew, we therefore draw 7 on Ainsworth $^{\mathrm{B}}$ data. 
Figure 1

Percent DWT incombustible content of Cherax quadricarinatus versus size for all 102 specimens ignited in this study.

The incombustible content of crayfish was not proportional to body size.

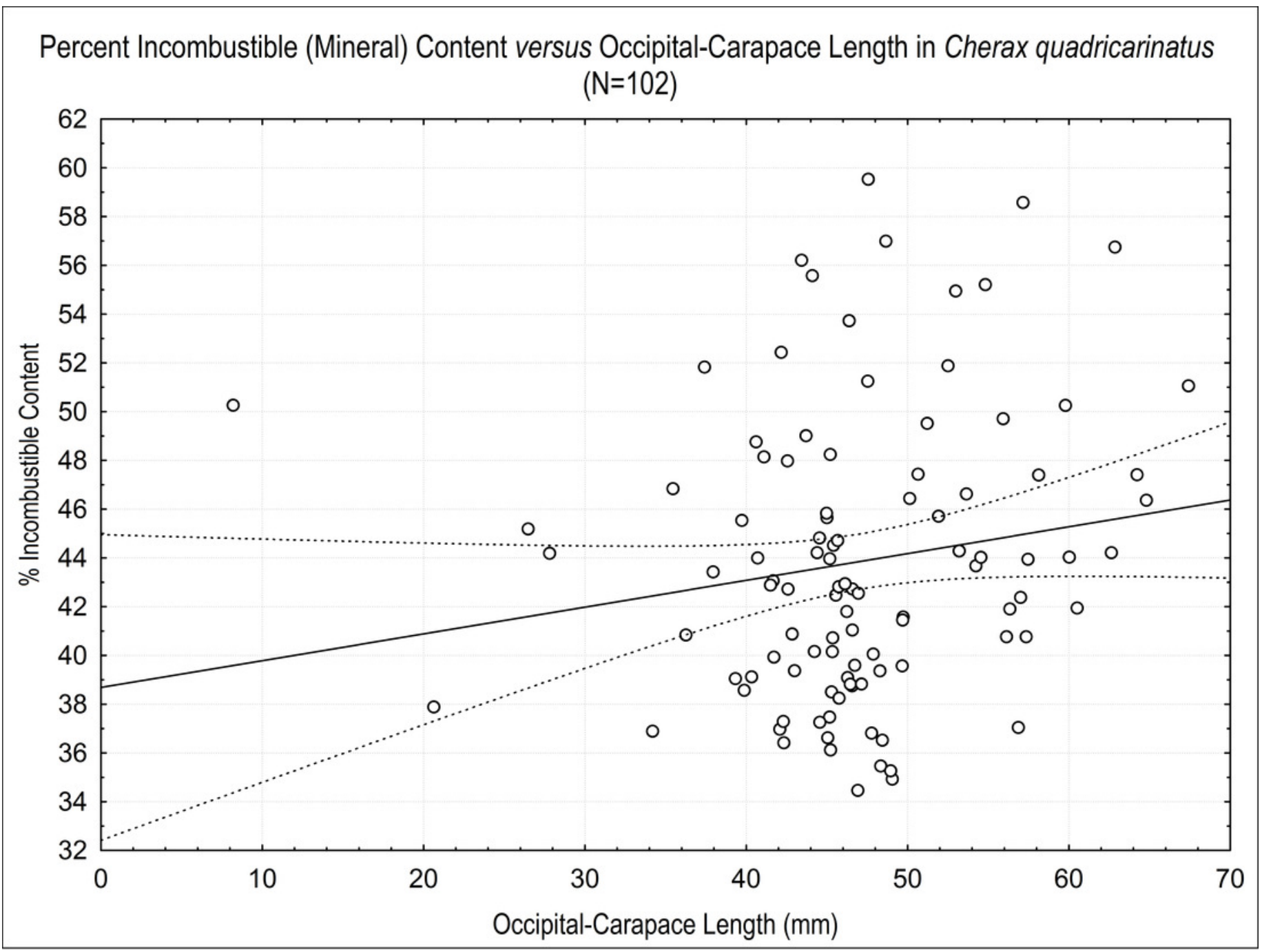


Figure 2

Boxplot of percent DWT incombustible content of Cherax quadricarinatus versus location of capture.

Specimens from Lake Ainsworth had significantly lower total incombustible content compared to Emigrant Creek Dam and Lake Somerset. Refer Table 1 for mean, and $\pm 95 \%$ Confidence Interval (C.I.) values associated with this boxplot.

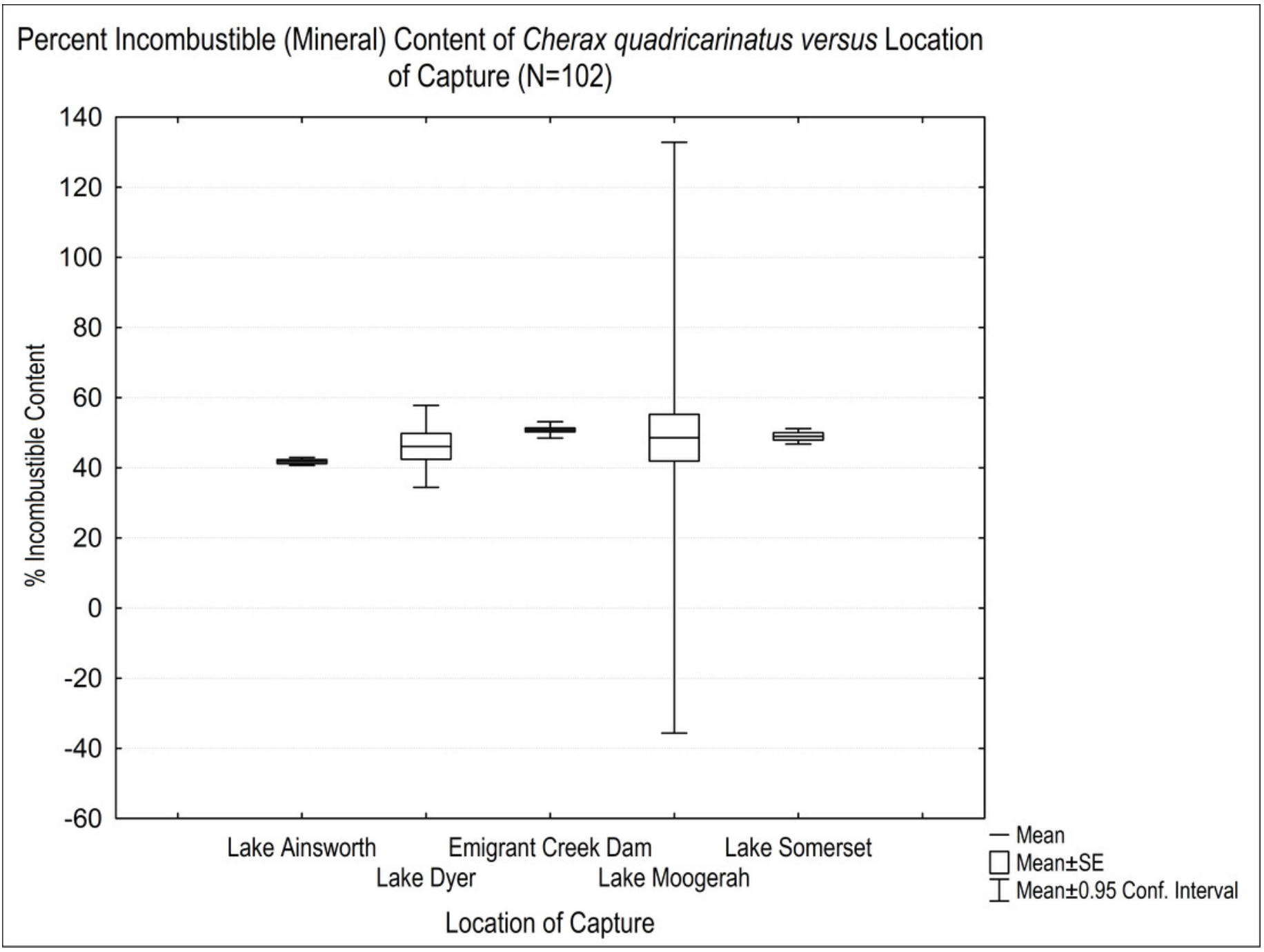

